\title{
Copyright Exceptions for Libraries in the Digital Age U.S. Copyright Office considers reform of Section 108, highlights of the symposium
}

$\mathbf{T}$ he U.S. Copyright Office held a symposium in conjunction with Columbia Law School's Kernochan Center for Law, Media and the Arts on February 8, 2013. Hosted at Columbia Law School, the symposium gathered together representatives of libraries, archives, authors, and publishers to address the current state of copyright exceptions for libraries embodied in Section 108 of the U.S. Copyright Act, and to examine prospects for Section 108 reform.

In 2011, then incoming Copyright Registrar Maria Pallante announced a series of priorities and projects to be undertaken by the Copyright Office, key among them updating Section 108 for the digital age. As noted by panelist Richard Rudick, retired general counsel of John Wiley \& Sons, the original 108 exception was drafted in response to the exciting new technology of the photocopy machine. Despite some later changes to 108 made as a result of the Digital Millennium Copyright Act, it was widely agreed among the panelists that Section 108 has not aged well. While the rise of digital media and technologies have fundamentally changed the way in which copyrighted works are made, distributed, preserved, and accessed, Section 108 has not kept pace. The end result of the law's outdatedness is its increasing failure to provide libraries and archives with appropriate and meaningful copyright guidance in the Digital Age.
In her opening remarks, Maria Pallante reiterated the Copyright Office's view that reform of Section 108 is crucial for both libraries and rights holders. Libraries play a central role in the diffusion of knowledge, and thus within the copyright system. In evaluating and proposing changes to library exceptions, the stated goal of the Copyright Office is to allow libraries and archives to meet their responsibilities to preserve and provide access to content, while not unduly affecting the incentives that copyright protection creates for authors to produce creative works. Without reform of Section 108, Pallante emphasized, the exception will continue to become increasingly useless, narrowly tailored to bygone technologies.

In the view of the Copyright Office, the alternative to reforming such a woefully outdated exception is to repeal Section 108 and leave libraries to rely solely on fair use, an outcome it considers unfair to both users and owners. With fair use comes uncertainty, disagreement, the risk of litigation, and the need for lawyers. As noted by several panelists, a

Melissa A. Brown is scholarly communication librarian at New York University Libraries, e-mail: melissa@nyu.edu

Contact Claire Stewart-series editor, head of digital collections and scholarly communication service at Northwestern University-with article ideas, e-mail: claire-stewart@northwestern.edu

๑) 2013 Melissa A. Brown 
key virtue of 108 is its potential to provide clear and specific guidance to practitioners on certain library activities, complementing and potentially reinforcing the flexible (some may add unpredictable) and fact-specific nature of fair use.

\section{Section 108 Study Group}

The current push for Section 108 reform is not the first in recent memory. Between 2005 and 2008, the Section 108 Study Group, convened by the Copyright Office and comprised of stakeholders, including a mix of both copyright owners and users, grappled with how to best update Section 108 to reflect the realities of the digital age. The resulting Section 108 Study Group Report, issued in 2008, helped to frame the panelists' discussion of current prospects for reform (indeed, several symposium panelists had participated in the 108 Study Group, whether as members or interested stakeholders) on both a substantive and political level.

The symposium weighed several specific recommendations issued in the 2008 study group report, and on some points there was fairly widespread agreement that there were, at least in principle, desirable reforms to be implemented.

For example, the addition of museums into the Section 108 exceptions appeared to enjoy widespread support. Several specific recommendations were geared towards giving libraries greater flexibility to reproduce and provide access to preservation and replacement copies made under Section 108 subsections (b) and (c), such as allowing libraries to create a "reasonable number" of copies and to circulate digital copies off-premises. The current language of Section 108 (b) and (c)—providing that digital preservation and replacement copies may not be made available to the public outside the premises of the library-was called out as a particularly outdated and burdensome restriction on library access. With digital materials, access to content is granted not to a physical location but to a user community.

Library and archive representatives also sought clearer rights to preserve published materials. Section 108 (b), the exception allowing reproduction for purposes of preservation, currently applies only to unpublished works. This limitation is a source of frustration for archivists, because publication status can be incredibly difficult to determine, and because in the view of archivists, the crux of the issue is the irreplaceability of the work. Panelist Eric Harbeson of the University of Colorado Music Library noted that publication status may or may not correspond to irreplaceability and the need for preservation.

In framing library exceptions, many discussions and comments distinguished between exceptions purely for making digital preservation copies, and exceptions involving providing patrons with digital access to content. Representatives of the library and archive communities expressed a desire to have clear legal support for their preservation activities, including mass digitization efforts, when deemed appropriate. Panelists and audience members emphasized that digital preservation is not an activity that libraries undertake lightly, but do so with great thought, care, and coordination, not to mention at great expense.

\section{Mass digitization}

The Copyright Office also sought views on the possibility of enacting legislation on mass digitization for preservation purposes, an issue outside the scope of the Section 108 Study Group's recommendations. Paul Aiken of the Authors Guild expressed the view that any mass digitization must occur in consultation with rights holders, even if solely for "dark archive" preservation. Further discussion explored whether licensing and private agreements could or should play a role in library preservation activities, with views ranging from "always" to "sometimes" to "never."

Library preservation exceptions were also considered in terms of who should be undertaking digitization, and how it should be accomplished. For example, do all libraries and archives need to have a preservation exception, or should this exception be limited 
to certain trusted institutions or perhaps only the Library of Congress? Embedded within this discussion were concerns and issues of trust among rightsholders as to whether libraries and archives can adequately safeguard digital content against risks of hacking, unlawful dissemination by third parties, or mission creep owing to the pressure put on libraries by their patrons to provide ubiquitous digital access to content.

Digital security risks and the anxieties they provoke for content owners likewise colored discussions to amend Section 108 to explicitly allow libraries to provide digital copies via ILL or patron delivery services. The scope of an exception for patron copies was also up for debate-in the view of Mark Seeley, counsel for Elsevier, market solutions and negotiated license agreements are better equipped to access library access needs than legislation, excepting for "long-tail" users and content that may not have a market solution available and thus would be appropriate for a copyright exception.

The role of licensing was raised by library advocates, as well, though unsurprisingly from a somewhat different point of view. For current digital content, library reproduction rights are governed by license terms and conditions, rather than the public copyright law. Given the potential for these license terms to erode core library access practices such as ILL, a goal of Section 108 reform should be to prevent licensing terms from effectively undermining any library exception that were to be enacted. Panelists pointed out that, in reality and by necessity, libraries already commonly provide digital copies based on fair use, or as characterized by Jonathan Band, based on using fair use "as a gloss on" Section 108.

Broader discussions on the relationship between libraries, archives, and copyright law illustrated the complexity of determining the appropriate scope of Section 108, and thus the desirability or effectiveness of trying to reform it. A number of crucial issues, including mass digitization and orphan works, e-reserves, licensing restrictions, and the complexity and length of copyright term, also bear heavily on the missions of libraries and archives, but are not within the current scope of Section 108 nor the Study Group Report.

Yet another obstacle is the inability of libraries to legally collect digital content that is not licensed for institutional or educational uses, such as content from iTunes or Amazon.

Intertwined with the scope and interpretation of 108 is the availability of fair use as a separate legal basis on which libraries and archives can rely to preserve and disseminate content in accord with their missions. Several of the Section 108 Study Group's recommendations have already been put into practice by libraries based on claims of fair use. For example, Mary Minow pointed to the study group's recommendation for an exception to allow Web archiving as something that has been adopted by libraries as "common law." Similarly, William Maher expressed that the goal for archives is to be able to provide full access to their collections online, when appropriately within fair use, and that an exception limited to individual digital access would do little to advance access to archival materials.

The availability of fair use as a legal alternative to Section 108 prompted discussion as to whether opening up Section 108 for reform is desirable. In the words of Jonathan Band, many within the library community may ultimately prefer to rely on federal judges rather than the current Congress. Band also expressed concerns that the copyright landscape is currently too fraught with disagreement and tension to expect any meaningful consensus or solution. The fear is that opening up 108 for reform will be in effect to open a can of worms, with the potential that libraries will end up with legislation that leaves them worse off than they are now.

Other panelists were less skeptical of the potential to reach consensus and reform. Representatives of libraries and archivists pointed out that practitioners want and need certainty, something that Section 108 can provide much better than fair use. Rightsholders also seek certainty that library reproduction activities will be appropriate in scope and

(continues on page 214) 


\section{The Art Libraries Society of North America}

(ARLIS/NA) received a $\$ 69,000$ grant from the Getty Foundation that allowed up to 15 librarians and art information professionals from Latin America to attend the ARLIS/NA 41st Annual Conference in Pasadena, California, in April. The grant covered all costs associated with conference attendance, including registration fees for programs and tours, travel and accommodation, and translation services. It is expected that the participation of the Latin American colleagues will lead to lasting professional collaborations, and will significantly expand ARLIS/ NA's representation of arts information professionals in the Americas.

\section{Acquisitions}

\section{The Jimmie Dodd Archive has been ac-} quired by the California Institute of the Arts (CalArts) Library. Dodd is known to the baby-boom generation as the host of Walt Disney's iconic 1950s children's television program The Mickey Mouse Club and remembered as The Mouse Club's "heart and the soul" by former Mousekateer Annette Funicello. During his career, the composer and actor compiled an archive of one-of-akind Mouse Club memorabilia and artifacts from the early years of television-including his Mousegetar, "mouse ears," original scores, record albums, photographs, toys, and other objects. The collection also contains archival materials from his wife, songwriter and performer Ruth Carrell Dodd. The process of organizing the material has begun, and it will take some time to properly prepare the archive for public access due to the large number of items. CalArts

Ed. note: Send your news to: Grants \& Acquisitions, C\&RL News, 50 E. Huron St., Chicago, IL 60611-2795; e-mail: agalloway@ala.org. was chosen to house the Dodd archive because of its relationship to the Disney family. The institute was founded by Walt Disney and his brother Roy O. Disney through the merger of the Los Angeles Conservatory of Music and the Chouinard Art Institute in 1961. Dodd started his career as a guitarist/singer before becoming an actor. Prior to The Mickey Mouse Club, he appeared in numerous films with such actors as William Holden, Fred Astaire, Judy Garland, John Wayne, and Ronald Reagan. In the early 1950s, he transitioned to the new medium of television, making guest appearances on several series of the time. While hosting The Mickey Mouse Club he also wrote its theme song, "The Mickey Mouse Club March." z

("Copyright Exceptions ...," cont. from page 201)

will adequately address security concerns, an issue that is not well addressed within the framework of fair use.

Across the spectrum of content users and owners, there was a desire to see greater flexibility in the law according to the type of use and the type of work, including the age of the work and its commercial viability. There was a general recognition that the one-size- fitsall approach of much of copyright law is not well-suited to library preservation and access activities. For example, there may be legitimate reasons to regard archival materials quite differently from commercial works when crafting library exceptions.

Throughout the symposium, the Copyright Office gathered views from both the panelists and the audience, which had in attendance many members of the library, archive, publishing, and legal communities. From this event and other efforts to engage with stakeholders through meetings and public discussions, the Copyright Office plans to formulate a discussion document and preliminary recommendations on Section 108 reform. $\boldsymbol{n}$ 